\title{
ANTROPOLOGIA GROBÓW CIALOPALNYCH CMENTARZYSKA DZIEKANOWICE 22
}

\author{
THE ANTHROPOLOGY OF CREMATION GRAVES \\ IN THE DZIEKANOWICE 22 GRAVE FIELD
}

\begin{abstract}
The article presents the analyses and descriptions of two graves in the Dziekanowice grave field, site 22 (dated back to the late $10^{\text {th }}$ - the late $13^{\text {th }}$ centuries) located on the eastern coast of lake Lednica, approx. $90 \mathrm{~m}$ from the eastern bridge leading to Ostrów Lednicki. The isle hosts a hillfort regarded a seat of the then ruler, the sedes regni principales. Within the gord, in the second half of the $10^{\text {th }}$ century, a complex of residential and sacral buildings was raised: a baptistery, a palas and a church. The burial rite as of the late $10^{\text {th }}$ and the early $11^{\text {th }}$ centuries, which appeared in what is now Poland's territory, is typically associated with Christianity encroaching the area. The issues under discussion, which are not fully explained, include both the ways in which the dead were buried before skeletal burials were introduced and popularised, the methods used to promote the changes, acceptance thereof, the rate and the prevalence of the new mode of burying the dead. In the course of extended excavations in the Dziekanowice 22 grave field, 1,665 graves have been discovered with preserved bone material, among them two graves where cremated bodies were laid (cremation burial). The graves have been dated back to the early Middle Ages (the time of the grave field's operation).
\end{abstract}

Keywords: Ostrów Lednicki, Dziekanowice site 22, early medieval grave field, skeletal graves, cremation graves, anthropological analysis.

Cmentarzysko Dziekanowice, stanowisko 22, gmina Łubowo pochodzi z okresu od końca X po koniec XIII wieku (Wrzesiński 2010, s. 63; 2016, s. 16 - tam wcześniejsza literatura). Zlokalizowane jest na wschodnim brzegu jeziora Lednica, około $90 \mathrm{~m}$ od wschodniej przeprawy mostowej na Ostrów Lednicki. Na wyspie tej znajduje się grodzisko zaliczane do siedzib ówczesnych władców kraju Piastów - sedes regni principales. W obrębie grodu, w 2. połowie X wieku, stanął kompleks budynków o charakterze rezydencjonalno-sakralnym - baptysterium, palatium oraz

* ORCID 0000-0000-0003-0603-356X, Pracownia Antropologiczna, Muzeum Pierwszych Piastów na Lednicy, Dziekanowice 32, 62-261 Lednogóra, e-mail: przyroda.aw@lednica.pl

** ORCID 0000-0003-0603-365X, Rezerwat Archeologiczny Gród w Grzybowie oddział Muzeum Pierwszych Piastów na Lednicy, Grzybowo 10A, 62-300 Grzybowo, e-mail: jaled@wp.pl. 
kościół (Żurowska [red.] 1993; Kurnatowska i Wyrwa [red.] 2016). Podczas wieloletnich badań cmentarzyska odkryto w jego obrębie 1665 grobów, a szczegółowa analiza antropologiczna ${ }^{1}$ pozwoliła na ujawnienie 1730 osobników pochowanych na przebadanym obszarze ${ }^{2}$ (Wrzesińska 2016, s. 155).

Wczesne średniowiecze to okres, gdy na znacznych obszarach Europy zachodziły przemiany zarówno osadnicze, gospodarcze, polityczne, jak i ideologiczne oraz religijne. W tym też czasie obserwujemy zmiany obrządku pogrzebowego, a informacji odnośnie do zachodzących przemian dostarczają między innymi materiały pozyskiwane w wyniku archeologicznych badań wykopaliskowych. Należy jednak zaznaczyć, iż archeologia dostarcza materialnych dowodów pochowania. Natomiast odtworzenia skomplikowanego ceremoniału pogrzebowego i związanej z nim obrzędowości dokonuje się na podstawie analizy źródeł historycznych, odkryć archeologicznych, dopuszczalnych analogii oraz spojrzenia retrospektywnego.

Obrządek pogrzebowy, jaki w końcu X i na przełomie X i XI wieku pojawia się na terenach współczesnej Polski, powszechnie łączony jest $\mathrm{z}$ wkraczaniem chrześcijaństwa na ten obszar. Nowa religia i wiara w jednego Boga została przyjęta przez ówczesną elitę i stopniowo (?) akceptowana przez ogół mieszkańców domeny Piastów. Do problemów wciąż dyskutowanych i nie w pełni rozstrzygniętych należą zarówno sposoby chowania zmarłych przed pojawieniem i upowszechnieniem się obrządku szkieletowego, jak i metody przekonywania do zmian, ich akceptacja, tempo i rozmiar - powszechność nowego sposobu chowania zmarłych.

Archeologiczne badania wykopaliskowe prowadzone w obrębie cmentarzysk dotykają sfery transcendencji, momentów, gdy człowiek w bezpośredni sposób styka się z sacrum. Sam moment pochowania, niezależnie od okresu i obszaru kulturowego, w jakich się dzieje, wymaga wykonania szeregu czynności, zabiegów, rytuałów. Związany jest z okresem przejściowym, dotykając tych, którzy pozostają na ziemi, i jest tym bardziej skomplikowany, im silniejsze były więzi między odchodzącym a zostającymi (van Gennep 2006, s. 151-156). Rzeczywistość wczesnego średniowiecza odsłaniamy między innymi podczas archeologiczno-antropologicznych badań stanowisk sepulkralnych, starając się ją interpretować w zgodzie z obowiązującymi aktualnie kryteriami i stanem naszej wiedzy. Wielokrotne przypominanie o obowiązku chowania zmarłych na cmentarzach i ogólne zasady sposobu ich grzebania pojawiają się dość często w źródłach historycznych. Dotyczą one jednak raczej samego składania zmarłych na wydzielonych miejscach grzebania $\mathrm{z}$ akcentowaniem, niezbyt chyba silnym i niezbyt konsekwentnie przestrzeganym, dbałości o skromną formę pochówku. Takie wskazówki znajdujmy zarówno

\footnotetext{
${ }^{1} \mathrm{~W}$ badaniach udział antropologa pozwalał na wykonywanie bezpośrednio na stanowisku ekspertyz i analiz materiału osteologicznego, a następnie weryfikowanie ich w trakcie rozmaitych prac gabinetowych.

${ }^{2}$ Przebadany obszar obejmuje około $11848 \mathrm{~m}^{2}$, co stanowi około $85 \%$ terenu, jaki cmentarz obejmował.
} 
w tekstach z wieku VIII, jak i czasów późniejszych z XI, XII czy XIII stuleci (por. Labudda 1983, s. 55-59; Zoll-Adamikowa 1988, s. 208; Dąbrowska 1997, s. 8-12). Informacje o przedchrześcijańskich obyczajach i obrzędach wplecione są w XIII-wieczny Katalog magii Rudolfa (Karwot 1955). A do czasów nowożytnych przeżywały się rozmaite formy i zwyczaje uważane za przeżytki starych, przedchrześcijańskich wierzeń i zwyczajów (por. Fischer 1921; Bylina 2002).

Problematyka przemian obrządku pogrzebowego była wielokrotnie podnoszona (patrz np. Zoll-Adamikowa 1971, s. 541-556; 1971a, s. 139-155; 1988, s. 183-229; Rębkowski 2007, s. 89-161; Urbańczyk 2015, s. 129-142; 2020). Nie wdając się w tę dyskusję, która wymaga głębszych studiów, chcielibyśmy przedstawić przykład cmentarzyska szkieletowego, gdzie nadrzędne kryterium - inhumacja - bez wątpienia sytuuje je wśród nekropolii chrześcijańskich. Właśnie inhumacja staje się podstawowym wyróżnikiem pozwalającym zaliczyć do chrześcijańskich nie tylko omówione cmentarzysko, ale też cały szereg podobnych w charakterze zagospodarowania i sposobie grzebania zmarłych. Wspomniana nekropola leży na obszarze Wielkopolski, między Poznaniem a Gnieznem. Na szkieletowych cmentarzyskach wczesnego średniowiecza dostrzegamy zunifikowany obrządek pogrzebowy i obserwujemy ogólne zasady organizacji przestrzeni grzebalnej pozwalające łączyć owe nekropole z nowym porządkiem wierzeniowym, nową wiarą ${ }^{3}$. Zaliczamy do nich zarówno samą inhumację, jak i chowanie zmarłych na wydzielonych miejscach w pozycji wyprostowanej, na plecach, z rękoma wzdłuż ciała, o generalnej osi ułożenia na linii wschód-zachód ${ }^{4}$. Dodatkowo na większości nekropoli widoczne jest zachowanie pewnego porządku charakteryzującego się sytuowaniem grobów w bardziej lub mniej czytelnych rzędach. A spotykane dość często uszkadzanie grobów przez kolejne pochówki jest potwierdzeniem wydzielonego, ograniczonego obszaru cmentarza, a także wskazówką jego wielopokoleniowego użytkowania.

$\mathrm{Na}$ dziekanowickim cmentarzysku wśród 1665 grobów wczesnośredniowiecznych z zachowanym materiałem osteologicznym (Wrzesińska 2016, s. 155) zarejestrowano dwa groby, w których znalazły się spalone szczątki ludzkie. To jedyne przykłady na tej nekropolii kremacji zmarłych współwystępującej z nową formą pochówku w postaci szkieletowego obrządku pogrzebowego. Być może te dwa (birytualne) groby możemy uznać za ostatni łącznik pomiędzy wspomnianymi

3 Proces chrystianizacji był zapewne długotrwały. Kościół i jego struktury w X wieku ograniczały się do najważniejszych ośrodków grodowych. Za czasów Bolesława Chrobrego, od momentu pojawienia się św. Wojciecha i jego śmierci prawdopodobnie możemy mówić o wzmocnieniu politycznego znaczenia władcy i silniejszym rozwoju Kościoła, ale o bardziej konsekwentnym procesie umacniania się jego struktury możemy mówić po połowie XI wieku, a o zdecydowanej stabilizacji w wieku XII (Dobosz 2002, s. 24-171; Sikorski 2011, s. 83-90; Sikorski 2012, s. 211-220).

${ }^{4}$ Oczywiście od owych generaliów obserwujemy odstępstwa. W Europie średniowiecznej już w VI-VII wieku pojawiają się zalecenia o chowaniu zmarłych ze skrzyżowanymi rękoma (por. Zoll-Adamikowa 1971a, s. 39-40; Dąbrowska 1997, s. 8-10). 
zmianami kulturowymi. W obydwu grobach ciałopalnych pochowani zostali osobnicy dorośli, płci żeńskiej (kobiety), a ich jamy grobowe zostały wkopane w groby wcześniejsze tego cmentarzyska (chronologicznie starsze), w których złożono szkieletowe pochówki dorosłych osobników płci męskiej. Groby datujemy na czasy wczesnego średniowiecza (na czas funkcjonowania cmentarzyska, tj. od końca X po XIII wiek) $)^{5}$.

\section{OPIS GROBÓW}

Grób 67a/96 (ryc. 1). Zarys jamy grobowej o kształcie zbliżonym do prostokąta z zaokrąglonymi narożnikami, o zachowanej długości $230 \mathrm{~cm}$ i szerokości $130 \mathrm{~cm}$ (w partii W) oraz $90 \mathrm{~cm}$ (w partii E). Jama była sytuowana wzdłuż osi E-W (oś odchylenia $13^{\circ}$ ). Strop jamy grobowej zarejestrowano na poziomie 113,17 m n.p.m., poziom warstwy spalonych kości zarejestrowano na poziomie 113,11-113,09 m n.p.m., a spąg jamy na poziomie 112,99-112,98 m n.p.m (wyznaczał go strop jamy i kamienie pochówku szkieletowego - grób 67/96). Zarys jamy grobowej odsłonięto na głębokości $62 \mathrm{~cm}$, pochówek ciałopalny został zarejestrowany na głębokości $68-70 \mathrm{~cm}$, a jego spąg na głębokości $80-81 \mathrm{~cm}^{6}$. W grobie na całej przestrzeni zarejestrowano spalone kości ludzkie, w większości bardzo drobne (dominował silnie rozdrobniony miał spalonych kości). Największe skupisko większych fragmentów spalonych kości zarejestrowano w partii południowej środka jamy i w partii północno-zachodniej jamy (ryc. 1). Spalone szczątki ludzkie należały do jednego osobnika, kobiety zmarłej w wieku Maturus, tj. około 40-50 roku życia. W jamie grobowej nie zarejestrowano żadnych przedmiotów osobistych.

Grób ciałopalny został wkopany w strop starszego grobu 67/96 i zalegał nad pochówkiem szkieletowym (ryc. 2), którego jama grobowa miała zarys regularnego prostokąta o długości $240 \mathrm{~cm}$ i szerokości $80 \mathrm{~cm}$. Grób wkopany był w glinę calcową. W jamie, za czaszką i za stopami, ustawione były pojedyncze większe kamienie (średnica około $25 \mathrm{~cm}$ ). Jama i pochówek sytuowane były wzdłuż osi E-W, szkielet czaszką zorientowany był w kierunku zachodnim (oś odchylenia na południe $15^{\circ}$ ). Poziom niwelacyjny stropu jamy grobowej 112,99-112,98 m n.p.m.,

${ }^{5}$ W trakcie badań w roku 1992 odsłonięto również pojedynczy pochówek zwierzęcy, pochówek konia, datowany metodą 14C na wczesne średniowiecze - BP $1100 \pm 100$ (Wrzesińska i Wrzesiński 1998, s. 109). Po zakończonej eksploracji warstw wczesnośredniowiecznych odsłonięto sześć grobów ciałopalnych o formach popielnicowych (cztery na zwartej przestrzeni w skraju północno-wschodnim badanego obszaru, a dwa w partii centralnej) datowane wstępnie na schyłkową fazę kultury łużyckiej (Wrzesiński [red.] 2016, plan cmentarzyska nr 3), a w partii zachodniej odsłonięto pojedynczy szkielet dorosłego, 35-letniego mężczyzny (grób 18/92), datowany metodą 14C na okres wpływów rzymskich, I w. n.e. (Wrzesińscy 1996, s. 325-338).

${ }^{6}$ Poziom poniżej współczesnej powierzchni użytkowej. 


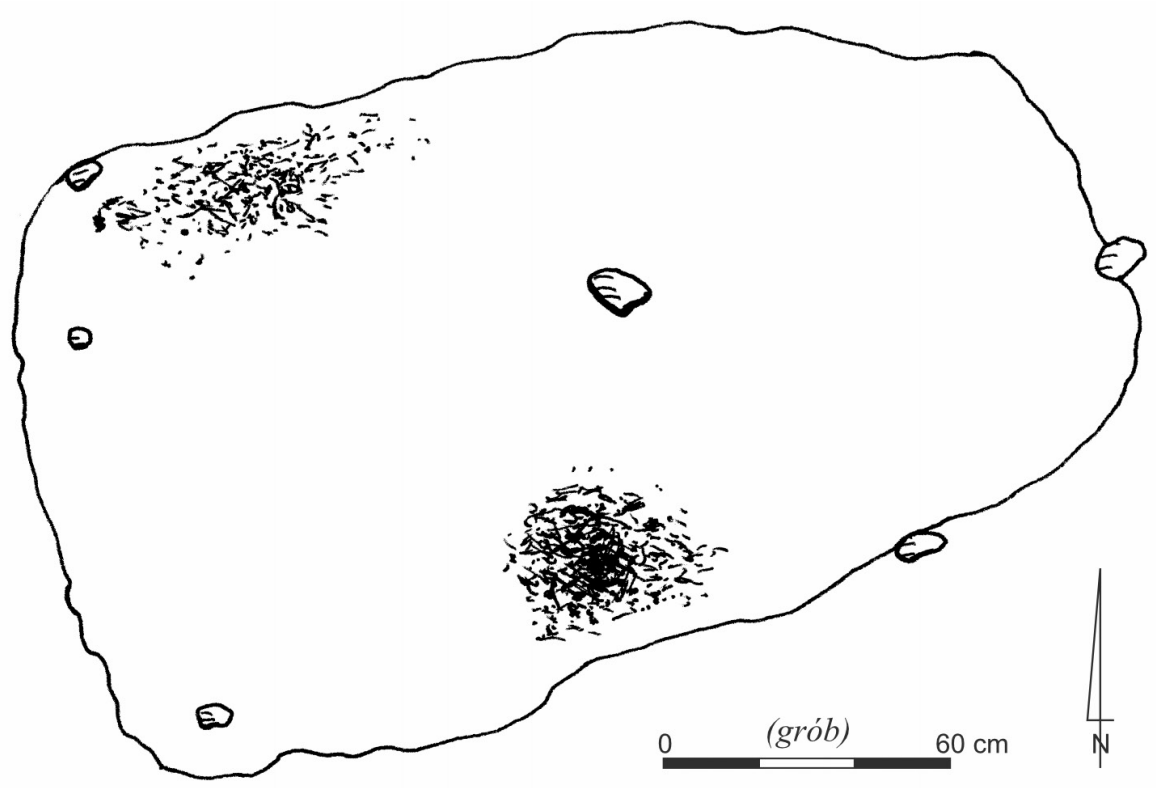

Ryc. 1. Dziekanowice, stan. 22. Grób ciałopalny 67a/96. Rys. M. Łomnicki. Opracowanie komputerowe T. Kasprowicz

poziom szkieletu 112,83-112,81 m n.p.m., spąg grobu 112,73-112,72 m n.p.m. Grób odsłonięto na głębokości 80-81 cm, szkielet na głębokości 96-98 cm (czaszka kości kończyn dolnych), a spąg grobu na głębokości 106-107 cm. W grobie złożono pochówek mężczyzny zmarłego w wieku Adultus-Maturus, tj. około 30-40 roku życia. W jamie grobowej przy szkielecie, po stronie lewej, zarejestrowano dwa przedmioty: wzdłuż lewego biodra wystąpił nóż żelazny jednostronny o długości całkowitej 16,6 cm, szerokości ostrza 1,5 cm, grubości grzbietu 0,5 cm, z dwustronnie wyodrębnionym trzpieniem (nr inw. 203/96 - ryc. 2:1). Na powierzchni ostrza widoczna zmineralizowana skóra - pozostałość pochewki (?). Na lewej miednicy przedmiot żelazny - przebijak o długości całkowitej $5 \mathrm{~cm}$, szerokości $1,0 \times 0,5 \mathrm{~cm}$ wykonany $\mathrm{z}$ podłużnej sztabki metalowej o przekroju prostokątnym. Jeden koniec przedmiotu tępy, drugi zaostrzony (nr inw. 201/96 - ryc. 2:2).

Grób 66/07 (ryc. 3, 4, 5). Zarys jamy grobowej był zbliżony do prostokąta o zaokrąglonych narożnikach i nieregularnych ścianach dłuższych. Jama była sytuowana wzdłuż osi E-W (oś $15^{\circ}$ ). Strop jamy grobowej stanowiło siedem dużych kamieni (o średnicach $40 \mathrm{~cm}, 30 \mathrm{~cm}, 20 \mathrm{~cm}$ ) ułożonych obok siebie w centralnej partii jamy. Kamienie te (i kilka mniejszych) odsłonięto na poziomie 114,30-114,29 m n.p.m., a na poziomie 114,24-114,19 m n.p.m. zadokumentowano pierwsze drobiny spalonych kości. Jama miała długość $270 \mathrm{~cm}$ i szerokość 80-100-65 cm (poziom I) (ryc. 3). Po 


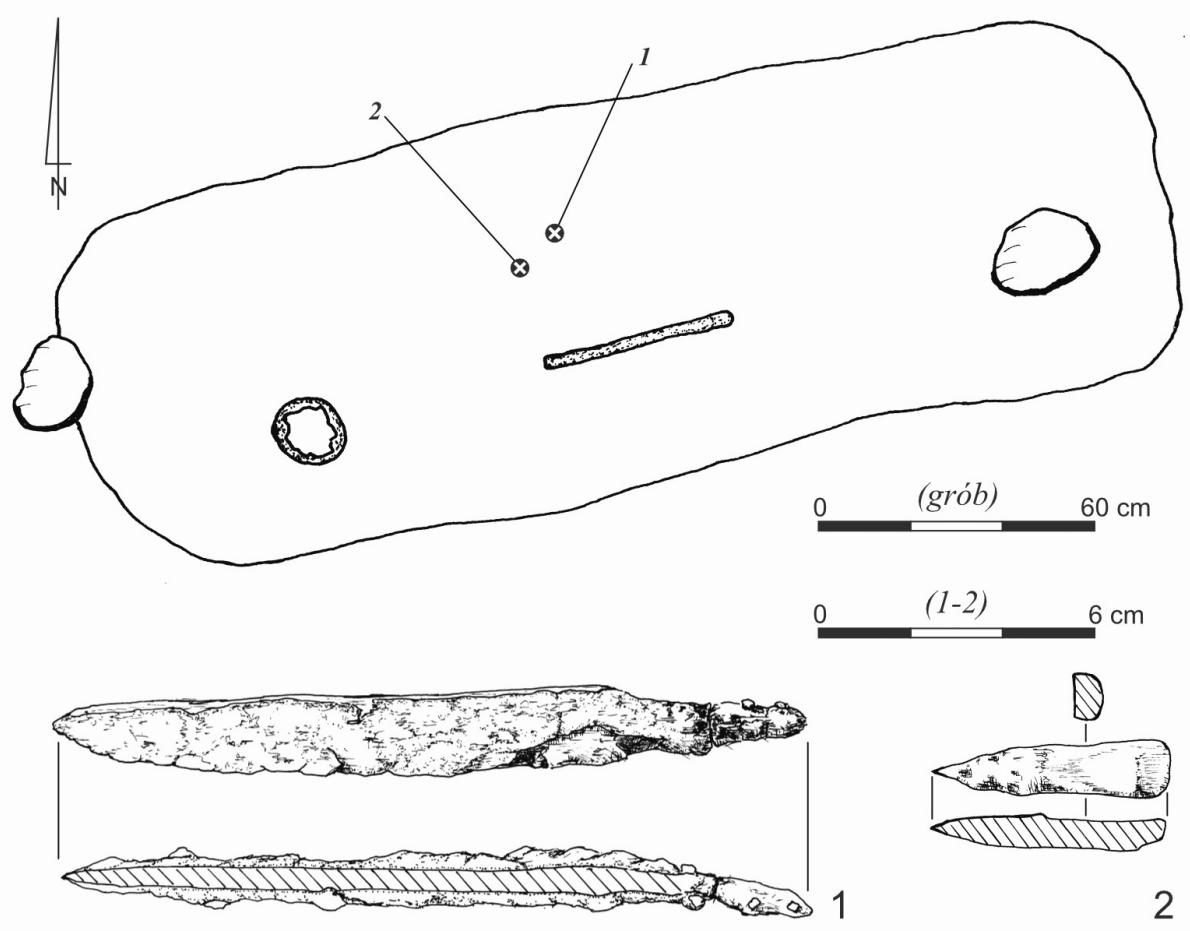

Ryc. 2. Dziekanowice, stan. 22. Grób szkieletowy 67/96 (1 - nóż żelazny; 2 - przedmiot żelazny). Rys. M. Łomnicki. Opracowanie komputerowe T. Kasprowicz

zdjęciu kamieni, na poziomie 114,10-114,05 m n.p.m., w jamie zarejestrowano drobne spalone kości (poziom II). W toku dalszej eksploracji wypełniska (do poziomu 114,02-113,98 m n.p.m.) jama przybrała kształt bardziej regularnego prostokątna o długość $250 \mathrm{~cm}$ i szerokość 75-70-120 cm. W jamie (niemal na całej długości) odsłonięto warstwę spalonych kości ludzkich i pierwsze drobne fragmenty niespalonych kości długich z pochówka szkieletowego wraz z przedmiotami wyposażenia grobowego (poziom III) (ryc. 4). Na poziomie 114,01-113,90 m n.p.m. odsłonięto anatomiczny szkielet dorosłego osobnika (69/07) i kolejne warstwy dużych fragmentów spalonych kości osobnika dorosłego (poziom IV grobu ciałopalnego) (ryc. 5). Jama była prostokątna o długości $250 \mathrm{~cm}$ i szerokości 110-80-110 cm. $\mathrm{Na}$ tym poziomie warstwa ciałopalna występowała na całej długości jamy z kumulacją licznych fragmentów w partii zachodniej. Szkielet był uszkodzony wkopem grobu ciałopalnego - przemieszczeniu uległa czaszka, fragmenty kości miednicznych i fragmenty kości długich dolnych kończyn. W jamie zarejestrowano trzy przedmioty. Spąg grobu zarejestrowano na poziomie 113,82-113,81 m n.p.m. Bruk kamienny uchwycono na głębokości $26-27 \mathrm{~cm}$, grób ciałopalny (poziom I) 


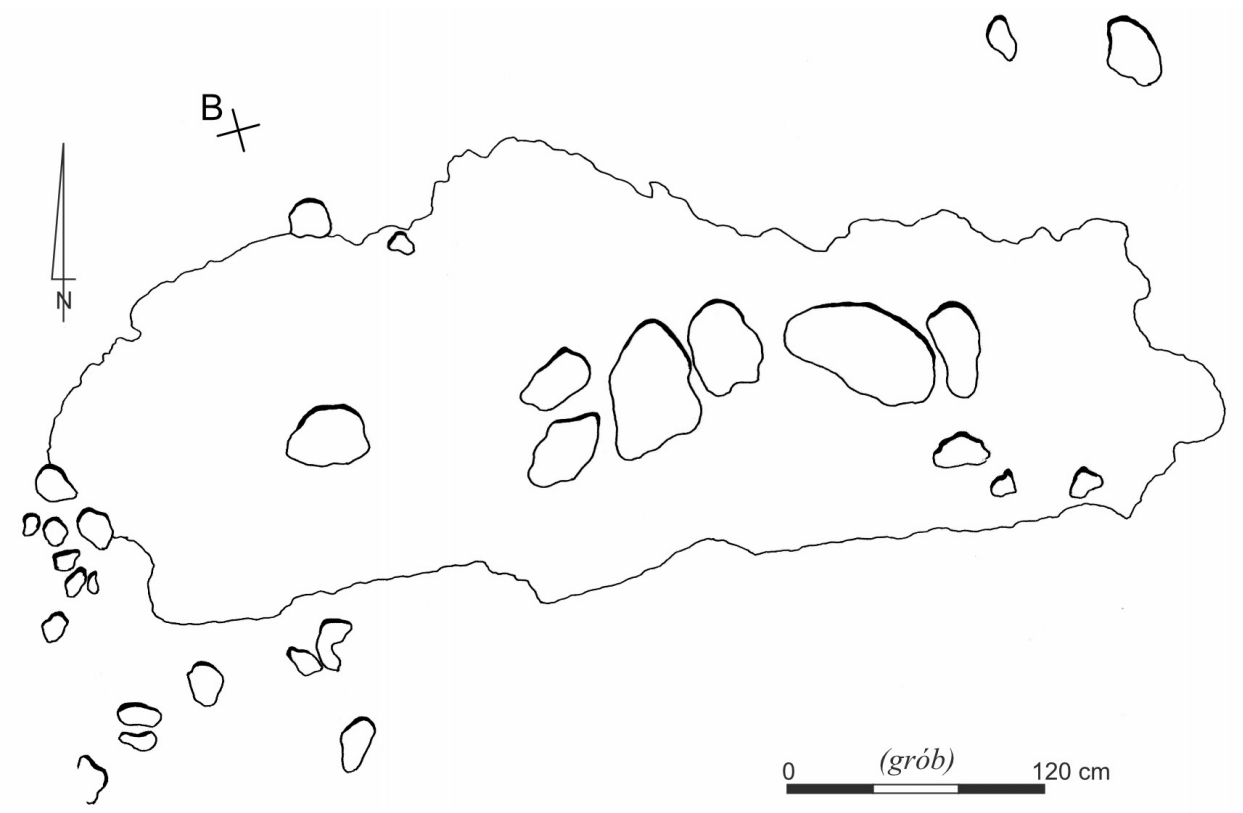

D

Ryc. 3. Dziekanowice, stan. 22. Grób ciałopalny 66/07 - poziom I. Rys. M. Łomnicki. Opracowanie komputerowe T. Kasprowicz

odsłonięto na głębokości $32-37 \mathrm{~cm}$. Szkielet uszkodzony grobem ciałopalnym (poziom IV) odsłonięto na głębokości 55-66 cm (czaszka - kości kończyn górnych). Grób ciałopalny wkopany w grób szkieletowy zalegał od głębokości $32-37 \mathrm{~cm}$ do głębokości 74-75 cm (poziom I, II, III, IV). Spąg obu grobów zarejestrowano na głębokości $74-75 \mathrm{~cm}$. W pierwotnym (chronologicznie starszym) grobie złożony był pochówek mężczyzny zmarłego w wieku Maturus, tj. około 35-45 lat. Szkielet prawdopodobnie ułożony był wąsko, w „całunie”, kończyny górne były blisko tułowia. Zmarły pochowany został w pozycji wyprostowanej, złożony na grzbiecie, na wznak, czaszką pierwotnie ułożoną w kierunku zachodnim (oś odchylenia na południe $\left.15^{\circ}\right)$. W grobie $\mathrm{W}$ ułożeniu anatomicznym zachowały się kości klatki piersiowej i obie kości ramienne (czytelne in situ), kościec kończyn dolnych uchwycono fragmentarycznie w partiach spągowych grobu. Przemieszczeniu uległa kompletna czaszka wraz z żuchwą (nieuszkodzone), co świadczy o niecelowym uszkodzeniu pierwszego pochówku - czaszka została złożona w skraju wschodnim jamy, na kościach dolnych kończyn (na stopach). W miejscu wyjętej czaszki (partia zachodnia jamy) złożono największe skupisko spalonych kości. Nie widzimy tutaj celowego usuwania wszystkich kości szkieletu z jamy i złożenia kości 


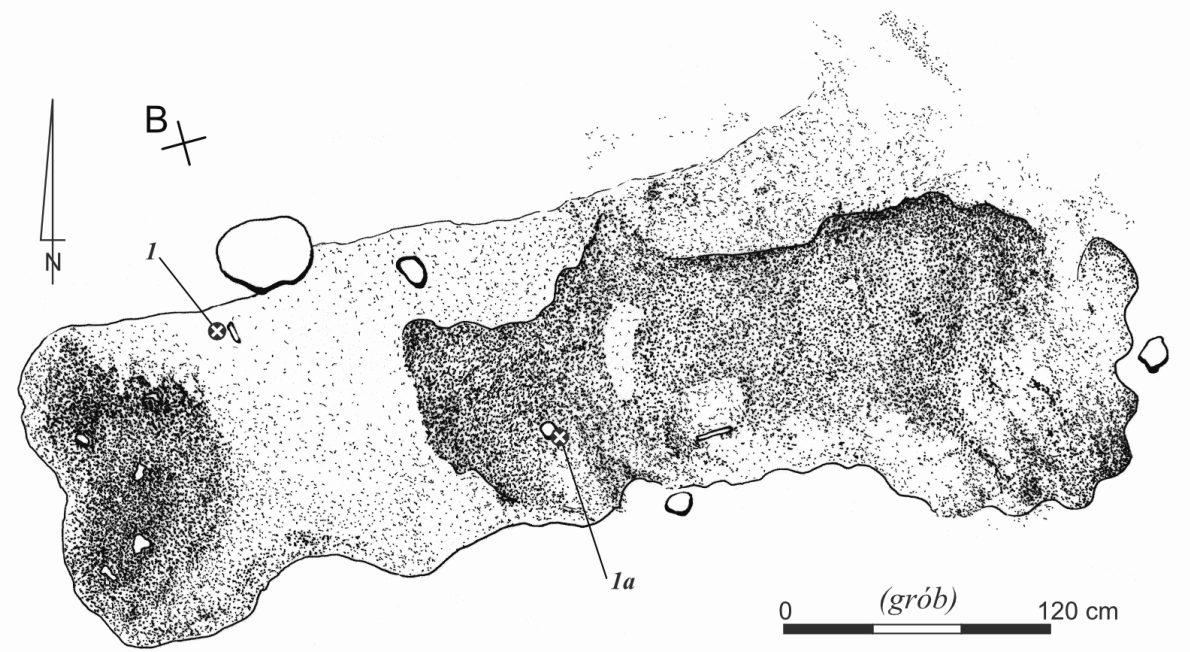

Ryc. 4. Dziekanowice, stan. 22. Grób ciałopalny 66/07 - poziom III. Rys. M. Łomnicki. Opracowanie komputerowe T. Kasprowicz

w skraju grobu. Nie widzimy tworzenia wolnej przestrzeni jamy do złożenia kolejnego zmarłego. Przeciwnie, w całej jamie starano się rozsypać kości spalone, jakby dokładano drugi pochówek. Częściowemu uszkodzeniu uległy tylko przedmioty towarzyszące pierwszemu zmarłemu (ryc. 6).

Czy do grobu 69/07 celowo dołożono pochówek ciałopalny 66/07, czy natrafiono na niego przypadkowo, trudno to stwierdzić (ryc. 7). Wykorzystanie tej samej jamy pierwotnie pojedynczego grobu i złożenie w niej kolejnego pochówku po upływie pewnego czasu jest często spotykaną praktyką zarówno na cmentarzysku dziekanowickim, jak i innych nekropolach wczesnego średniowiecza (Wrzesińska i Wrzesiński 2002, s. 77-88). Obserwuje się też wielokrotne wykorzystywanie tego samego miejsca dla złożenia kilku kolejnych zmarłych. Wkopywanie zmarłych w to samo miejsce powoduje najczęściej silne uszkodzenia pierwotnego pochówku, a fragmenty kośćca bywają częściowo usuwane, rozproszone lub układane w jamie, tworząc jedno lub kilka często niekompletnych skupisk. Zjawisko to spowodowane było zapewne intensywnym użytkowaniem cmentarzysk o ograniczonym obszarze. Długa chronologia wielu cmentarzysk wskazuje na wykorzystywanie przez kilka pokoleń tego samego miejsca dla celów sepulkralnych.

Mimo że upływ czasu pomiędzy kolejnymi grobami jest trudny do określenia, niemniej jest wyraźnie czytelny na analizowanym przykładzie. Odsłaniając grób i szkielet 69/07 i wkładając szczątki zmarłego 66/07 spalonego uprzednio na stosie, z należytą starannością przełożono czaszkę wraz z żuchwą (nierozdzielone), nie uszkadzając jej, nie niszcząc, a kładąc ją na nogach/stopach w ułożeniu na prawym 


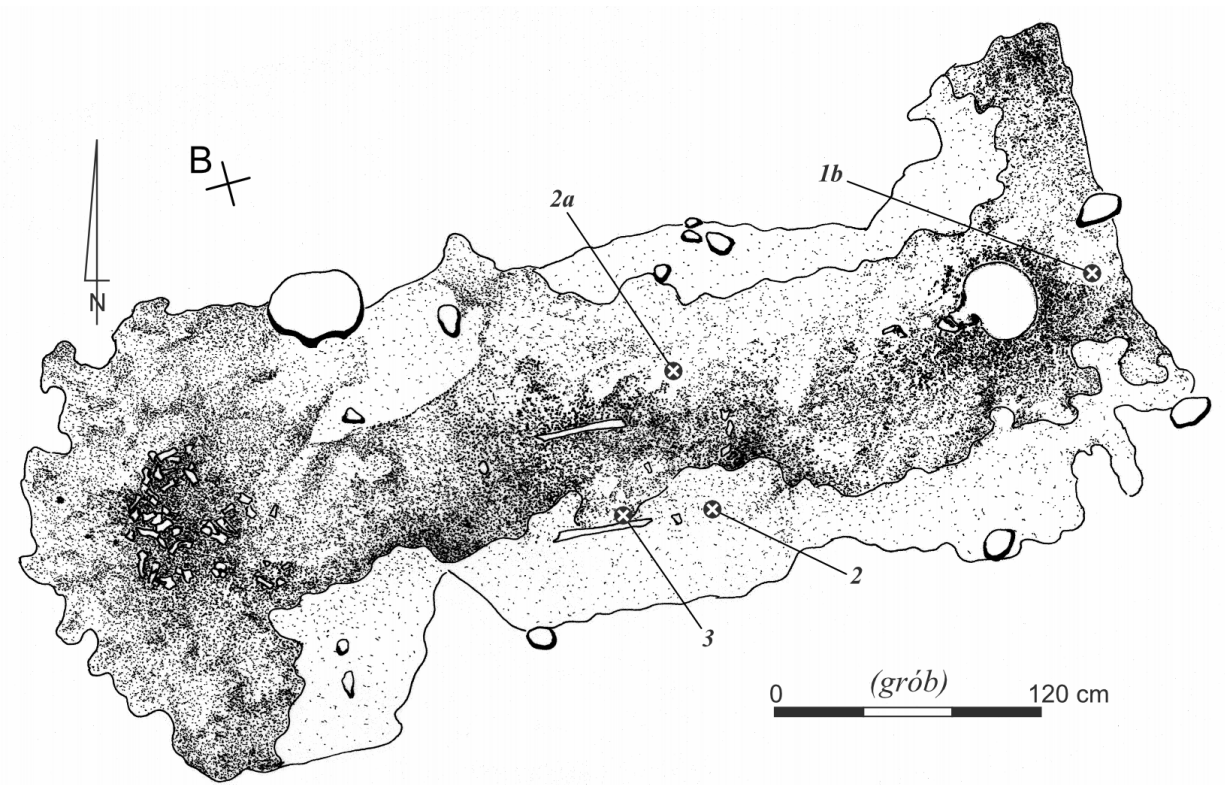

Ryc. 5. Dziekanowice, stan. 22. Grób ciałopalny 66/07 i pochowek szkieletowy 69/07 - poziom IV. Rys. M. Łomnicki. Opracowanie komputerowe T. Kasprowicz

boku/skroni w partii wschodniej jamy. Przy szkielecie zarejestrowano trzy przedmioty. Najbardziej wyjątkowy przedmiot, pierwotnie prawdopodobnie znajdujący się wzdłuż lewej strony szkieletu, to drzewce laski wykonanej z twardego drewna jesionowego (Fraxinus sp. $)^{7}$, zachowanej w trzech fragmentach. Pierwszy największy znaleziono wraz z kością lewego obojczyka w skraju NW jamy w obrębie poziomu III (ryc. 4). Było to żelazne okucie z zachowaną szczelnie owijającą drzewce tkaniną (nr inw. 55/07 - ryc. 6:1) o uchwyconej długości 3,5 cm, szerokość taśmy 1,5 cm, średnica „obejmy” 2,1 cm. Fragmentowi temu towarzyszył luźny fragment oddzielonej tkaniny o wymiarach $1,9 \times 1,1 \mathrm{~cm}$ (głębokość 113,97 m n.p.m.). $\mathrm{Na}$ poziomie III grobu (pośrodku jamy) znaleziono kolejny fragment drzewca tej laski (nr inw. 55/07 - ryc. 6:1a) o wymiarach 3,3 × 1,2 × 0,7 cm (głębokość 113,97 m n.p.m.). Trzecia część należąca do drzewca laski (fragment o wymiarach $2,3 \times 1,6 \times 1,8 \mathrm{~cm}$; nr inw. 55/07 - ryc. 6:1b) znajdował się na wysokości lewej stopy zmarłego (za przełożoną czaszką), w ramach wydzielonego poziomu IV. Był to fragment $\mathrm{z}$ niewielkimi dwoma brązowymi gwoździkami wbitymi w boczne ściany drzewca - naprzeciwlegle i z pojedynczym, wbitym od dołu, maleńkim

\footnotetext{
${ }^{7}$ Oznaczenie próbek drewna pod kątem ustalenia gatunku wykonał dr Tomasz Stępnik, któremu bardzo dziękujemy.
} 

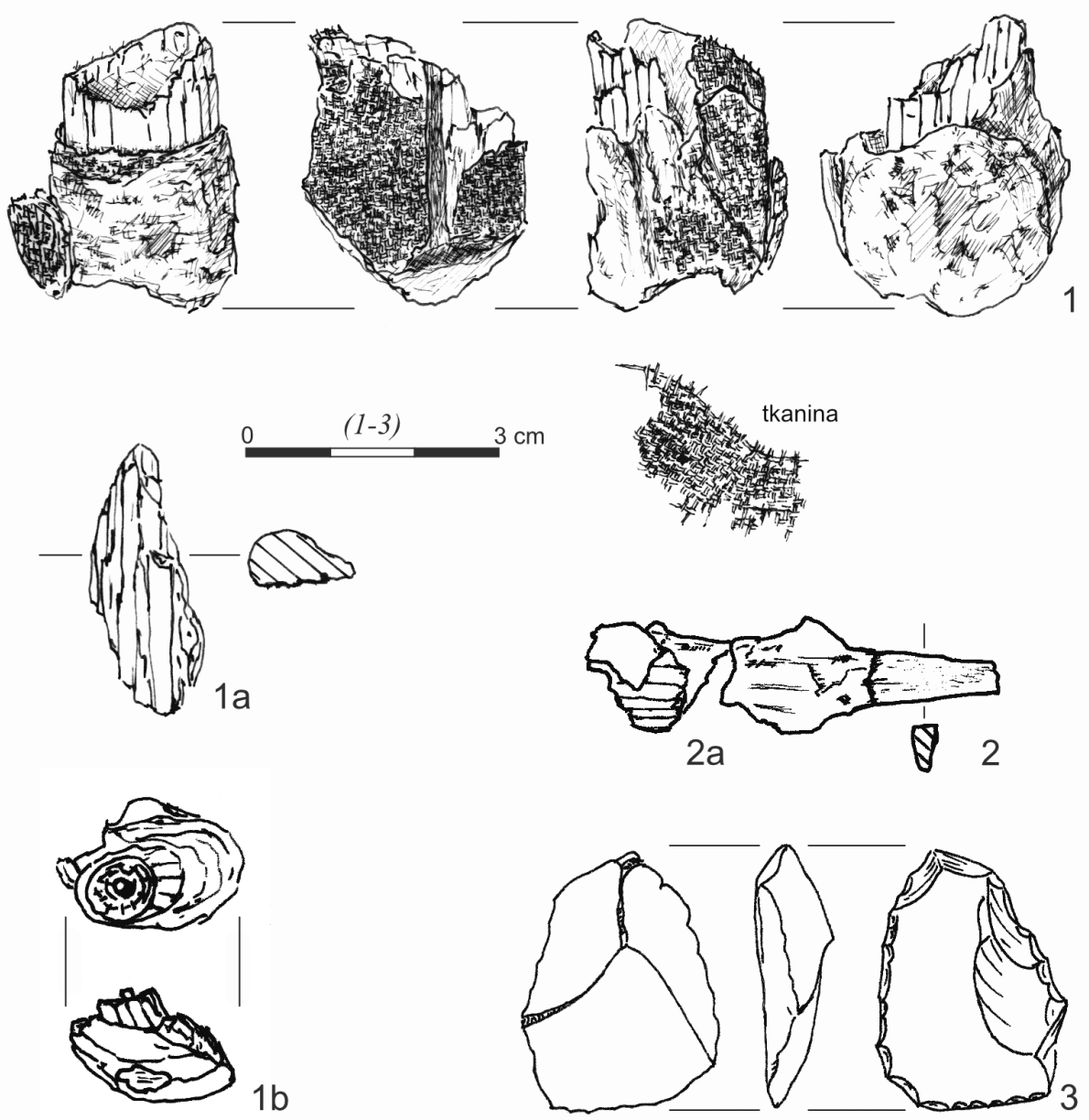

Ryc. 6. Dziekanowice, stan. 22. Zabytki z grobu szkieletowego 69/07 (1 - żelazne okucie drzewca laski z zachowaną tkaniną, 1a-1b - fragmenty drzewca; 2-2a - nóż żelazny; 3 - skrobacz krzemienny). Rys. M. Łomnicki. Opracowanie komputerowe T. Kasprowicz

kutym gwoździkiem srebrnym ${ }^{8} \mathrm{z}$ wyodrębnionym okrągłym łbem i haczykowato zagiętą zaostrzoną końcówką (głębokość 113,94 m n.p.m.). Długość gwoździka $0,9 \mathrm{~cm}$, szerokość łba $0,2 \mathrm{~cm}$. Odległość pomiędzy dwoma skrajnymi fragmentami laski wynosi $185 \mathrm{~cm}$.

Pozostałe zabytki wystąpiły przy szkielecie w ramach poziomu IV (ryc. 5). Po prawej stronie szkieletu (pas/biodro) znaleziono nóż żelazny jednostronny z trzpieniem (nr inw. 58/07 - ryc. 6:2) (113,96 m n.p.m.), drugi fragment tego noża

\footnotetext{
${ }^{8}$ Szczegółowa analiza surowcowa wymienionych gwoździ w toku.
} 

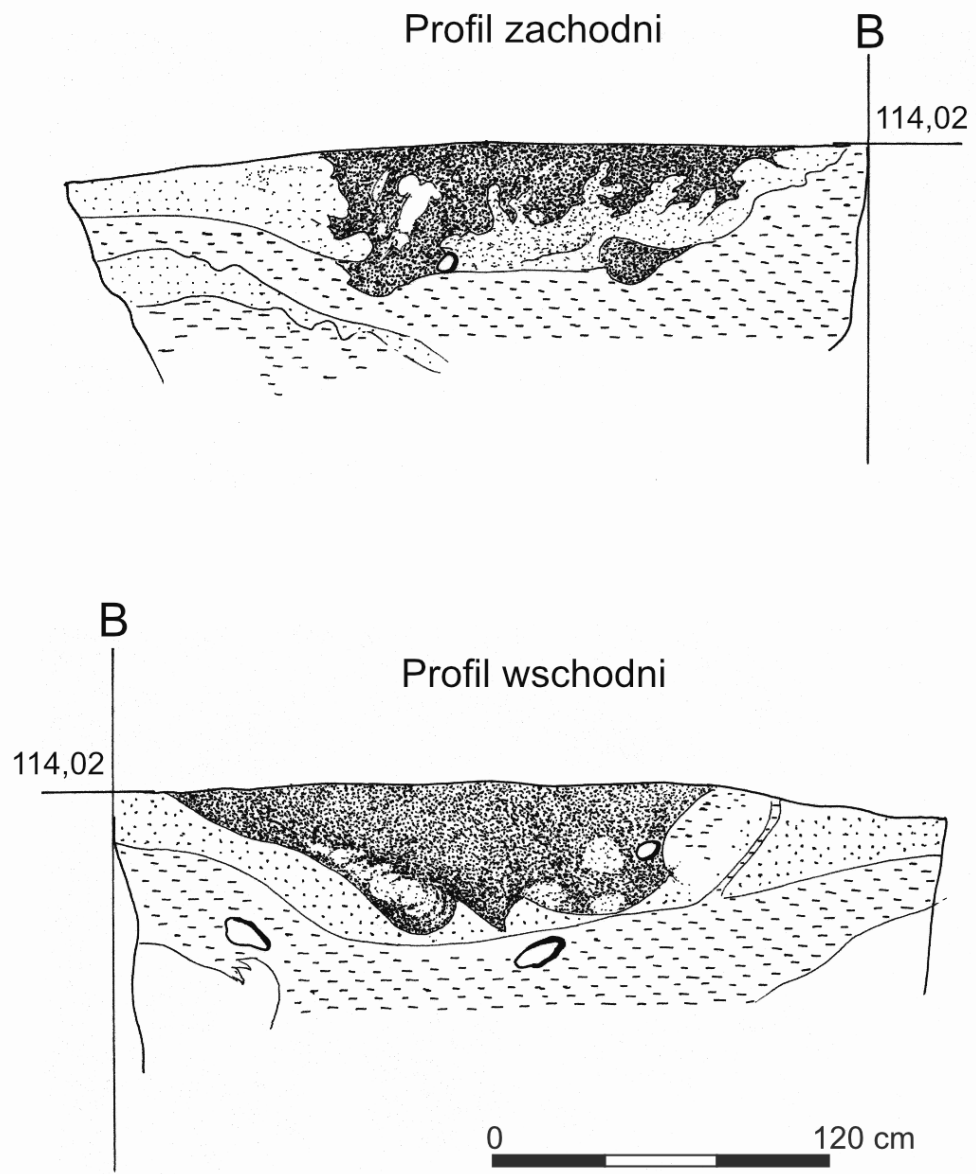

Ryc. 7. Dziekanowice, stan. 22. Profil zachodni i profil wschodni świadka (B) grobu ciałopalnego wkopanego w grób szkieletowy. Rys. M. Łomnicki. Opracowanie komputerowe T. Kasprowicz

znaleziono po stronie lewej zmarłego (nr inw. 58/07 - ryc. 6:2a) (113,89 m n.p.m.). $\mathrm{Na}$ fragmencie ostrza widoczne są ślady drewna (prawdopodobnie deski grobowej, na której złożono zmarłego 69/07 do grobu). Zachowana długość noża 4,7 cm, szerokość 1,1 cm, grubości 0,2 cm. Przy prawym ramieniu (na klatce piersiowej) znaleziono skrobacz krzemienny o dwóch krawędziach załuskanych (nr inw. 59/07 ryc. $6: 3)$, wymiary $3,1 \times 2,1 \times 0,8 \mathrm{~cm}(113,89 \mathrm{~m}$ n.p.m.). 


\section{EKSPERTYZA ANTROPOLOGICZNA}

Badania antropologiczne ciałopalnych szczątków kostnych są bardziej utrudnione i ograniczone aniżeli badania szczątków niespalonych. Analiza ta ma znacznie mniejsze możliwości rekonstrukcji procesów biologicznych i więcej utrudnień przy rekonstrukcji większości cech morfologicznego wyglądu człowieka. W badaniach tych mamy do czynienia jedynie z fragmentami kości, które są przepalone i silnie zmienione termicznie. Nie znaczy to, że badania spalonych kości nie poszerzają czy nie wzbogacają naszej wiedzy o ludziach stosujących taki obrządek pogrzebowy.

Podstawą badań przepalonych szczątków kostnych są przede wszystkim metody powszechnie znane i stosowane w badaniach szkieletów niespalonych. W przypadku fragmentów kostnych zmienionych termicznie istotne są informacje o wielkości, kształcie i barwie szczątków (Ubelaker 1989; Piontek 1999). Można określić stopień ich przepalenia, stosując 5-stopniową skalę Andrzeja Malinowskiego (1974). A ustalenie właściwej liczby zdeponowanych szkieletów w jednej jamie grobowej wymaga identyfikacji zarówno nieparzystych struktur anatomicznych szkieletu i ewentualnie ich zwielokrotnionej liczby, jak i parzystych cech anatomicznych.

Ekspertyzy antropologiczne zostały wykonane na podstawie metod wypracowanych zarówno dla materiałów ciałopalnych przez J. Strzałko, J. Piontka i A. Malinowskiego (1972; 1973), J. Piontka (1974; 1999) i D.H. Ubelakera (1989), a polegające na dokładnym segregowaniu materiału, opisie i pomiarach lepiej zachowanych fragmentów oraz określeniu liczby osób, ich wieku oraz płci, jak i dla materiałów szkieletowych (Acsádi i Nemeskéri 1970; Buikstra i Ubelaker 1994; Piontek 1999). Materiał szkieletowy z grobów, w które wkopane zostały groby ciałopalne, poddany został szczegółowej analizie z zastosowaniem metod oceny kompleksowej. Zmarłym zeszkieletowionym (67/96 i 69/07) i spalonym (67a/96 i 66/07) oznaczono wiek w chwili śmierci na podstawie zmian w morfologii powierzchni spojenia łonowego, powierzchni uchowatej kości miednicznej, na podstawie obliteracji zachowanych odcinków szwów czaszkowych oraz oceny zaawansowania procesów ossyfikacyjnych kości szkieletu postkranialnego (Ubelaker 1989; Piontek 1999). Wiek w chwili śmierci oznaczono, opierając się na 6-stopniowej skali oceny wieku według kryterium Andrzeja Malinowskiego i Władimira

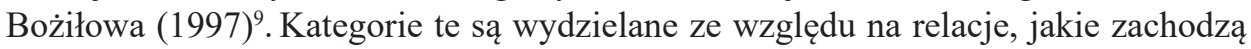
pomiędzy nasilaniem się zmian rozwojowych w organizmie człowieka a wiekiem biologicznym osobnika. Identyfikacja płci została dokonana na podstawie cech diagnostycznych identyfikowanych na materiale szkieletowym i ciałopalnym, na podstawie morfologii czaszki i miednicy oraz ogólnej masywności, wielkości oraz urzeźbieniu szkieletu postkranialnego (Acsádi i Nemeskéri 1970; Strzałko, Piontek

9 Wiek Infans I (dzieciństwo młodsze od 0 do około 6-7 lat), Infans II (dzieciństwo starsze od 6 do 12-14 lat), Juvenis (wiek młodzieńczy od 14 do 20-22 lat), Adultus (wiek dorosły od 22 do 30-35 lat), Maturus (wiek dojrzały od 35 do 50-55 lat), Senilis (wiek starczy powyżej 55 lat). 
i Malinowski 1973; Strzałko i Henneberg 1975; Piontek 1999). Wykonane zostały pomiary kranio- i osteologiczne na dobrze zachowanych odcinkach czaszki i na kościach długich, według ogólnie przyjętej w antropologii metodyki (Martin i Saller 1957).

\section{IDENTYFIKACJA MATERIAŁU PRZEPALONEGO}

Grób 67a/96 (wykop IV/1996) odsłonięty w południowej partii cmentarzyska.

Materiał kostny był rozdrobniony, niekompletny, charakteryzujący się małym zróżnicowaniem stopni przepalenia w obrębie tej samej warstwy ciałopalnej. Stosując skalę Malinowskiego (1974), odnotowano głównie słabsze stopnie przepalenia (od 1 do 2) barwy czarnej i brunatnej. Silniejsze (3, 4 i 5) nie wystąpiły.

Szczątki kostne eksplorowano w ramach dwóch najbardziej czytelnych skupisk w jamie. Oddzielnie w ramach partii południowej jamy i oddzielnie w ramach partii północno-zachodniej jamy (ryc. 1). Pozostałe fragmenty kostne w jamie były tak silnie rozdrobnione, że niemożliwa była ich eksploracja. Stan zachowania takich kości w grobach jamowych jest mało przydatny ${ }^{10}$. Kości rozdzielono do dwóch kartonów. W poszczególnych skupiskach rozpoznano następujące fragmenty kostne:

\section{Skupisko południowe. Ciężar kości 132,44 g}

Kości czaszki (bardzo słabo spalone, nadpalone, czarne, 1 stopień przepalenia) - duże fragmenty kości sklepienia czaszki - kość czołowa i kość ciemieniowa o grubości kości 4-5 mm, kość potyliczna o grubości 4,5-5,5 mm; uszkodzona piramida kości skroniowej; wyrostek stawowy prawej gałęzi żuchwy; fragment trzonu żuchwy prawej z otwartymi zębodołami ostatnich zębów trzonowych.

Kości szkieletu postkranialnego (1-2 stopień przepalenia) - liczne ułamki łuków kręgowych; drobne fragmenty żeber; fragmenty trzonu prawego i lewego obojczyka; wyrostek kruczy łopatki; fragment trzonu mostka; część talerza kości biodrowej (widoczny fragment powierzchni uchowatej), fragment gałęzi górnej kości łonowej i fragment spojenia łonowego - morfologia powierzchni spojenia łonowego wskazuje na wiek około 39-44 lat lub 45-50 lat (VIII lub IX wg T.W. Todda 1921 za Piontek 1999, s. 168); liczne ułamki trzonów kości długich (udowych i piszczelowych) - grubość istoty kostnej zbitej 5,5-7 mm.

10 Stan zachowania i rozdrobnienia kości zależy nie tylko od siły ognia na stosie, ale od wielu innych czynników. W grobach jamowych ulegają uszkodzeniu przez korzenie roślin, wpływ ma wilgotność gleby, jej przepuszczalność (wypłukiwanie) czy wrażliwość na zmiany temperatury (Pyżuk 2004, s. 35), jak również późniejsze użytkowanie obszaru dawnego cmentarzyska jako pola uprawnego - czego przykładem są Dziekanowice. Silne rozdrobnienie kości może być także wynikiem zwyczajowego kruszenia kości przed włożeniem do grobu. 


\section{Skupisko północno-zachodnie. Ciężar kości 17,61 g}

Kości czaszki (1-2 stopień przepalenia) - fragment kości czołowej z częściowo zachowanym górnym brzegiem prawego oczodołu (krawędź oczodołu prawdopodobnie ostra, gładyszka słabo zaznaczona); fragment kości jarzmowej; wyrostek sutkowaty kości skroniowej prawej (wąski, o wymiarach 9,5 × $5 \mathrm{~mm}$ ); drobne niezidentyfikowane ułamki puszki mózgowej (blaszki istoty zbitej rozwarstwione); pojedyncze ułamki kości ciemieniowych z zachowanym częściowo, na dwóch fragmentach, obliterowanym szwem strzałkowym (zakończona obliteracja egzokranialna).

Kości szkieletu postkranialnego (1 stopień przepalenia) - fragment trzonu kości ramiennej o grubości istoty kostnej zbitej $5,5 \mathrm{~mm}$.

Ponadto $\mathrm{w}$ jamie grobowej znajdowały się nierozpoznane, drobne fragmenty kostne.

Uzyskane informacje na temat stopnia zharmonizowania budowy morfologicznej, barwy i delikatności szczątków oraz obecności fragmentów kości parzystych pozwalają przypuszczać, iż skremowane szczątki należą do jednego osobnika płci żeńskiej. Zbadane na przepalonych kościach cechy odpowiadały zakresowi zmienności charakterystycznemu dla osobnika dojrzałego, zmarłego w wieku Maturus, tj. około 40-50 roku życia. Ciężar ${ }^{11}$ łączny wyeksplorowanych szczątków to tylko 150,05 g. Kości były źle, nie w pełni spalone. Dominowały kości barwy czarnej, o małym stopniu zdeformowania.

Grób 66/07 (wykop III/2007) odsłonięty jako ostatni grób północnego skraju cmentarzyska.

Materiał kostny stanowiły silnie i bardzo silnie przepalone szczątki kostne o 4 i 5 stopniu przepalenia, barwy złotawożółtej i białej ${ }^{12}$. Liczny materiał z grobu wyeksplorowano w czterech oddzielnych warstwach, z podziałem na partię zachodnią jamy o grubej warstwie ciałopalnej i partię wschodnią jamy z niewielką ilością silnie przepalonych fragmentów kostnych - mniejsza warstwa ciałopalna (ryc. 4 i 5), w których rozpoznano następujące fragmenty kostne:

${ }^{11}$ Ciężar kości - pozornie cecha mało ważna, dopełnia wiedzę o pochówku. Sugeruje czy wręcz wskazuje, że jest to pochówek wieloosobniczy, czy przypuszczalnie mężczyzny (lub kobiety), czy są to kości szkieletu kompletnego, czy tylko jego fragmenty (Pyżuk 2004, s. 35).

12 Barwa kości (z jej odcieniami) mówi zarówno o technice kremacji, jak i o stopniu przepalenia. Kości o barwie białej są najlepiej przepalone, pozbawione składników organicznych, kruche, spękane i najczęściej poskręcane, lepiej przechowujące się w ziemi. Dobrze spalone kości o bogatej strukturze gąbczastej są barwy złotawożółtej (od trójwartościowego żelaza hemoglobiny) (Pyżuk 2004, s. 35). 
Poziom 1 (partia E). Ciężar kości 1,83 g

Kości szkieletu postkranialnego - fragment łuku kręgowego jednego z kręgów szyjnych.

\section{Poziom 1 (partia W). Ciężar kości 40,64 g}

Kości czaszki - część piramidy kości skroniowej oraz nieliczne, cienkie ułamki puszki mózgowej o grubości 2,5-3 mm.

Kości szkieletu postkranialnego - fragmenty trzonów trzech kręgów piersiowych (na jednym widoczny na powierzchni trzonu ślad lizy kostnej - proces zapalny?); fragment głowy kości promieniowej ( $\geq 16 \mathrm{~mm})$; część głowy prawej kości udowej (widoczny fovea capitis femoris); ułamki żeber oraz liczne, drobne fragmenty trzonów i nasad kości długich.

\section{Poziom 2/3 (partia E). Ciężar kości 12,29 g}

Kości czaszki - nierozpoznane ułamki kostne.

Kości szkieletu postkranialnego - niewielkie fragmenty trzonów i łuków kręgowych oraz ułamki trzonów i nasad kości długich.

\section{Poziom 2 (partia W). Ciężar kości 53,01 g}

Kości czaszki - drobne ułamki puszki mózgowej z odcinkami szwów czaszkowych słabo/lub nieobliterowanych.

Kości szkieletu postkranialnego - część łuku kręgu lędźwiowego; fragmenty głowy i nasady dalszej prawej kości udowej; fragment prawej panewki kości miednicznej; odcinki kości łonowej i fragmenty prawego i lewego spojenia łonowego - morfologia powierzchni spojenia łonowego wskazuje na wiek około 27-30 lat (V wg T.W. Todda 1921 za Piontek 1999, s. 168).

\section{Poziom 3 (partia W). Ciężar kości 205,34 g}

Kości czaszki - prawy wyrostek czołowy kości jarzmowej o szerokości $10 \mathrm{~mm}$; fragment prawej kości czołowej (widoczny kąt górny przyśrodkowy oczodołu); 5 ułamków puszki mózgowej (kości o grubości charakterystycznej dla osobników dorosłych 4-5 mm); prawa gałąź żuchwy, gładka o łagodnym kącie z otwartym zębodołem po trzecim zębie trzonowym (M3 wypadł post morte).

Kości szkieletu postkranialnego - liczne fragmenty trzonów kręgów piersiowych i lędźwiowych; fragmenty żeber; środkowa część prawego obojczyka i luźno jego koniec barkowy; fragmenty głowy i kłykcia prawej kości ramiennej - widoczny bloczek kości (szerokość $\geq 21 \mathrm{~cm}$ ) i struktura dołu łokciowego; części prawej kości biodrowej z fragmentem powierzchni uchowatej oraz liczne ułamki trzonów i nasad kości długich. 


\section{Poziom 4 (partia E). Ciężar kości 5,06 g}

Niewielka liczba silnie rozdrobnionych, nierozpoznanych fragmentów kostnych.

Poziom 4 (partia W). Ciężar kości 530,22 g

Kości czaszki - 6 fragmentów puszki mózgowej (kość potyliczna o gładkiej rzeźbie, kresa karkowa słaba, grubość kości 4-4,5 cm).

Kości szkieletu postkranialnego - fragmenty trzonów 4 kręgów (3 piersiowych i lędźwiowego); liczne ułamki łuków kręgowych; fragmenty żeber; koniec barkowy lewego obojczyka oraz bardzo liczne ułamki trzonów (grubości istoty kostnej zbitej 3-5,5 mm) i nasad kości długich (o delikatniej rzeźbie i małej masywności kośćca).

Oceniając przynależność płciową zachowanych części szkieletu, wykorzystano elementy diagnostyczne kości czaszki, kości miednicznych i kości kończyn dolnych, tj. delikatna i gładka kość czołowa; stopień wykształcenia gładyszki; stopień wykształcenia kresy karkowej; ogólna rzeźba i budowa żuchwy; słaba masywność kośćca; mała średnica panewki stawowej prawej kości miednicznej; rzeźba trzonów kości długich; małe wymiary głowy kości promieniowej i mała wielkość głowy prawej kości udowej. Dodatkowo przeanalizowano informację o ogólnej masywności kośćca, uwzględniając również liczne wycinki trzonów kości długich o nieznacznej grubości istoty kostnej zbitej, od $3 \mathrm{~mm}$ do 5,5 mm. Ostatecznie uznano, że zbadane cechy kośćca wskazują na osobnika płci żeńskiej. Ocenę wieku w chwili śmierci dokonano na podstawie analizy obliteracji zachowanych odcinków szwów czaszkowych, stopnia skostnienia nasad kości długich oraz na podstawie zmian morfologicznych na spojeniu łonowym. W grobie 66/07 pochowano kobietę zmarłą w wieku Adultus, tj. około 27-30 roku życia. Na jednym z kręgów piersiowych, na powierzchni trzonu widoczny był ślad lizy kostnej (proces zapalny). Prawdopodobnie początek choroby lub łagodnej postaci zmian zapalnych kręgosłupa polegający (w dalszym okresie życia) na rozpadzie tkanki kostnej mogącej prowadzić do powstawania ubytków kostnych, wywołujących silny ból i utrudniających poruszanie się osobnika (Gładykowska-Rzeczycka 1989, s. 23).

Ze względu na bardzo silne przepalenie i fragmentaryczność materiału kostnego podjęto próbę rekonstrukcji długości ciała na podstawie przybliżonego pomiaru średnicy głowy kości promieniowej, a także pomiaru szerokości bloczka kości ramiennej. Analizę przeprowadzono, opierając się na zaleceniach metodycznych: J. Strzałko, J. Piontek, A. Malinowski (1972; 1973) i J. Piontek (1999), a ich wartości znalazły się poniżej statystycznie przetestowanej wartości granicznej, odpowiadającej szkieletowi żeńskiemu. Uzyskane wyniki pozwoliły zakwalifikować odtworzoną długość ciała do kategorii „średnia” od $160 \mathrm{~cm}$ do $164 \mathrm{~cm}$. Zatem można stwierdzić, iż zbadane szczątki kostne należały do dorosłej, średniowysokiej kobiety.

Ciężar szczątków kostnych znalezionych w grobie wyniósł 848,39 g i wskazuje, że po wypaleniu stosu zostały one wybrane dokładnie i z dużą starannością. 


\section{ZAKOŃCZENIE}

Stosunek człowieka do śmierci jest ambiwalentny. Z jednej strony istnieje świadomość nieuchronności śmierci, przemijania, odejścia członka społeczności, utraty kogoś najbliższego. Z drugiej kieruje nami naturalny strach i niechęć do zmarłego oraz konieczność pozbycia się zwłok, ale zarazem troska o dalsze losy zmarłego. Zapewne stąd też wynika potrzeba konstruowania obrządku pogrzebowego będącego zbiorem praktyk religijnych i zwyczajów postępowania z trupem. I chociaż na terenach wczesnośredniowiecznej Słowiańszczyzny obserwujemy występowanie zarówno ciałopalnego, jak i szkieletowego obrządku pogrzebowego, to za najbardziej typowy sposób chowania zmarłych obowiązujący na tych terenach do połowy lub końca X wieku uważa się ciałopalenie (Zoll-Adamikowa 1988, s. 183; 1995, s. 175). O pierwotnym charakterze ciałopalenia u Słowian wspominają źródła pisane (Lewicki 1952-1953, s. 122-153; Lewicki 1977, s. 111-113; Zoll-Adamikowa 1979, s. 284; Powieść... 1968, s. 219; Labudda 1983, s. 37-38; Kronika Thietmara 2005, s. 218). Na obszarze władztwa Piastów przejście z obrządku ciałopalnego na szkieletowy odbywa się powoli i mimo upowszechnienia się inhumacji przeżywanie się ciałopalenia w różnych obszarach trwa nawet do XIII wieku.

Powstały w 3. ćwierci X wieku gród z chwilą pobudowania w latach 60 . tegoż stulecia w jego wnętrzu reprezentacyjnych budowli (palatium, kaplica przypałacowa i kościół) (Goslar, Pawlak i Wyrwa 2020, s. 323-350, tab. 1, tab. 2) staje się jedną z ważniejszych rezydencji Piastów. Jest ważnym ośrodkiem administracyjnym, kościelnym i centrum osadniczym. Na obszarze lednickim obserwujemy jeden z najwyższych wskaźników gęstości zaludnienia dla tego okresu wynoszący 10,5 osoby $/ \mathrm{km}^{2}$. I choć ranga tego ośrodka w 2. połowie XI wieku spada, to osadnictwo nadal sugeruje wyjątkowo wysoki wskaźnik. Pod koniec X wieku społeczność zamieszkująca tereny nad jeziorem Lednica postanowiła chować swoich zmarłych na wschodnim brzegu jeziora. Na ten cel wybrano niewielkie, łagodne wyniesienie, które miało bezpośredni kontakt wzrokowy, a dzięki mostowi także faktyczny, z Ostrowem i znajdującym się tam grodem, gdzie funkcjonował ważny ośrodek rezydencjonalno-sakralny domeny Piastów. Cmentarzysko w Dziekanowicach należy do największych nekropoli wczesnego średniowiecza rozpoznanych w znacznej części przez zespół archeologiczno-antropologiczny w ramach systematycznych i planowanych badań wykopaliskowych. Na cmentarzysku wyeksplorowano 1665 grobów (w tym cztery groby puste), w których zarejestrowano obecność 1730 zmarłych w różnym wieku i płci (Wrzesiński [red.] 2016). W okresie wczesnego średniowiecza pochowano tu co najmniej 1728 osobników w obrządku szkieletowym i dwa pochówki ciałopalne, po przeprowadzonej (w sąsiedztwie cmentarza) kremacji zmarłych. Te dwa pochówki były oddalone od siebie o 107 metrów. Jeden pochowano na północnym skraju cmentarzyska - grób 66/07 kobiety zmarłej w wieku Adultus 27-30 lat; drugi w strefie południowej - grób 67a/96 kobiety zmarłej w wieku Maturus 40-50 lat. Przygotowując zmarłych do pogrzebu, 


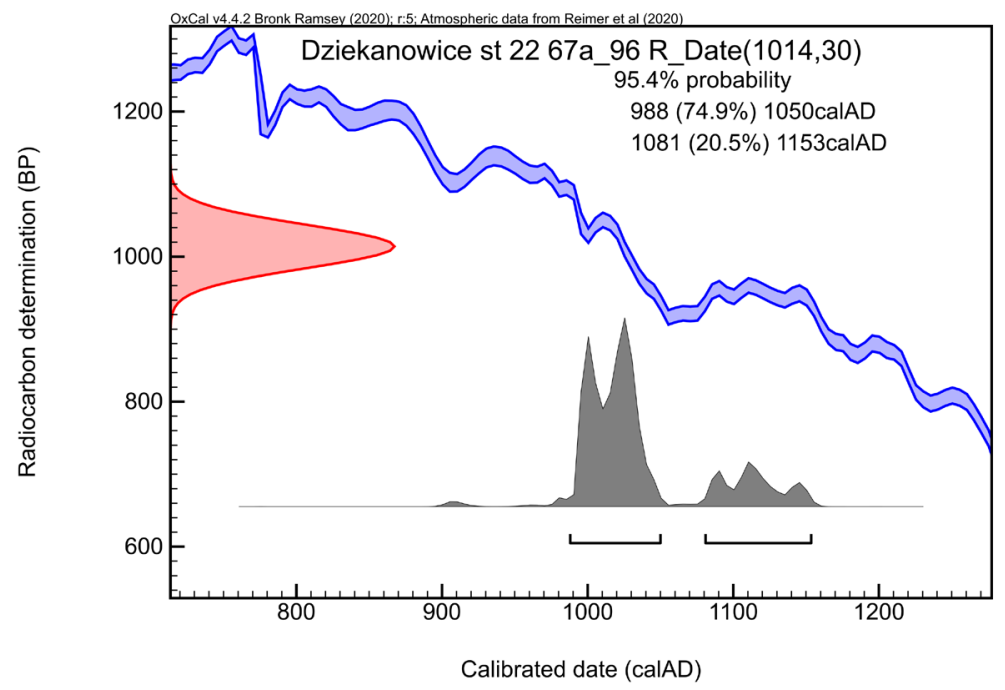

Ryc. 8. Dziekanowice, stan. 22. Wyniki datowania radiowęglowego 14C dla grobu 67a (Poznańskie Laboratorium Radiowęglowe, Nr lab. Poz-137096)

odpowiednio ich ubierano, często dawano im ich osobiste narzędzia, zakładano różnorodne ozdoby. Dodatkowo w trakcie obrządku chowania przekazywano zmarłym rozmaite przedmioty, palono ognie, $w$ jamie pozostawiano odpowiednie dary. Tylko $51 \%$ grobów tego cmentarzyska miało rozmaite wyposażenie - przedmioty z różnych metali, z kości, ceramiki, kamieni, z materiałów organicznych. Te jedyne dwa skremowane pochówki nie zostały obdarowane żadnymi przedmiotami. Sukcesywnie analizowane i opracowywane groby tego cmentarzyska (Wrzesiński [red.] 2019 - tam dalsza literatura) pozwalają na coraz bardziej przybliżoną prezentację ówczesnego sposobu traktowania zmarłych. Wraz z upływem czasu i prowadzonymi badaniami lepiej poznajemy obraz nieobecnych tej dawnej społeczności.

W rejonie Jeziora Lednickiego znanych jest kilka cmentarzysk wczesnośredniowiecznych ${ }^{13}$. Prócz dwóch omówionych grobów nie znamy dotąd innych ciałopalnych pochówków tego okresu z obszaru lednickiego. Pochówki obu kobiet spalonych i złożonych w miejscach (być może jeszcze czytelnych na powierzchni), gdzie wcześniej pochowano innych zmarłych. Spalone szczątki kobiet zebrano ze stosów ze starannością i rozlokowano w górnych partiach jam grobowych szkieletowych pochówków mężczyzn. Przygotowując miejsce złożenia dla spalonych

${ }_{13}$ Trzy spośród nich (Ostrów Lednicki, Dziekanowice, stan. 2, Dziekanowice, stan. 22) były poddane pracom wykopaliskowym. Natomiast dwa inne, znane z zapisków archiwalnych - na terenie dzisiejszej wsi Dziećmiarki i na terenie wsi Skrzetuszewo - uległy całkowitemu zniszczeniu. 
szczątków, zachowano nienaruszony (czy niemal nienaruszony - grób 69/07) szkielet. $\mathrm{Na}$ obecnym etapie badań rodzi się szereg pytań, na które nie potrafimy jednoznacznie odpowiedzieć. Jednym z nich jest pytanie, dlaczego w bezpośrednim sąsiedztwie znaczącego ośrodka religijnego związanego z kościołem dwie kobiety zostały pochowane w obrządku ciałopalenia. Ale też - czym motywowali się chowający, wracając do tradycyjnego sposobu chowania. Istotnym problemem do rozwiązania pozostaje też moment, w jakim dokonano tych pochówków ciałopalnych. W chwili obecnej ich chronologię możemy zamknąć w granicach początku wieku XI a wiekiem XIII ${ }^{14}$.

Niniejsza prezentacja dwóch wczesnośredniowiecznych grobów zdeponowanych w obrębie dużego cmentarzyska z obrządkiem szkieletowym ukazuje, jak bardzo niejednorodna była to społeczność, jak skomplikowanie przebiegał proces przemian kulturowych i duchowych. Ale także jak nasze wyobrażenia o tej społeczności dalekie są od choćby przybliżonego rzeczywistego jej obrazu.

\section{BIBLIOGRAFIA}

Acsádi G., Nemeskéri J. 1970, History of human life span and mortality, Budapest.

Buikstra J.E., Ubelaker D.H. 1994, Standads for Data collection from Human Skeletal Remains. Proceedings of a Seminar at The Field Museum of Natural History, Arkansas Archeological Survey Research Series, t. 44.

Bylina S. 2002, Chrystianizacja wsi polskiej u schyłku średniowiecza, Warszawa.

Dąbrowska E. 1997, Liturgia śmierci a archeologia: uwagi o wyborze miejsca pochowania, orientacji, ułożeniu ciała i jego ubiorze w średniowiecznej Europie Lacińskiej, „Kwartalnik Historyczny”, t. 104 , nr 4, s. 3-14.

Dobosz J. 2002, Monarchia i możni wobec Kościoła w Polsce do początku XIII wieku, Poznań.

Fischer A. 1921, Zwyczaje pogrzebowe ludu polskiego, Lwów.

Gennep van A. 2006, Obrzędy przejścia. Systematyczne studium ceremonii, Warszawa.

Gładykowska-Rzeczycka J. 1989, Schorzenia ludności prahistorycznej na ziemiach polskich, Gdańsk.

Goslar T., Pawlak E., Wyrwa A.M. 2020, Datowanie zabytków Ostrowa Lednickiego na podstawie analizy bayesowskiej dat radiowęglowych, w: D. Banaszak, A. Kowalczyk, A. Tabaka, A.M. Wyrwa (red.), Ostrów Lednicki - Palatium Mieszka I i Bolesława Chrobrego. Chronologia i kontekst, Fontes. Biblioteka Studiów Lednickich, seria B1, t. 9, s. 323-350.

Karwot E. 1955, Katalog magii Rudolfa. Źródto etnograficzne z XIII wieku, Polskie Towarzystwo Ludoznawcze, Prace Etnologiczne, t. 4, Wrocław.

Kronika Thietmara 2005, tłumaczenie, wstęp i przypisy Marian Zygmunt Jedlicki, Kraków.

Kurnatowska Z., Wyrwa A.M. (red.) 2016, Ostrów Lednicki. Rezydencjonalno-stoleczny ośrodek pierwszych Piastów, Origines Polonorum, t. 9, Warszawa.

Labudda A. 1983, Liturgia pogrzebu w Polsce do wydania Rytuału Piotrkowskiego (1631): studium historyczno-liturgiczne, Warszawa.

Lewicki T. 1952-1953, Obrzędy pogrzebowe pogańskich Stowian w opisie podróżników i pisarzy arabskich, głównie z IX-X w., „Archeologia”, t. 5, s. 122-153.

${ }^{14} \mathrm{~W}$ czerwcu 2021 roku uzyskano datę $14 \mathrm{C}$ dla grobu $67 \mathrm{a}$ (ryc. 8) zamykającą się w granicach 988 a 1050 (przy wiarygodności 74,9\%) (Poznańskie Laboratorium Radiowęglowe Nr lab. Poz137096). Dziękujemy Panu prof. dr hab. Tomaszowi Goslarowi za przekazaną informację. 
- 1977, Źródta arabskie do dziejów Stowiańszczyzny, t. 2, cz. 2, Prace Komisji Orientalistycznej, nr 14, Wrocław.

Malinowski A. 1974, Historia i perspektywy antropologicznych badań grobów cialopalnych, w: H. Giżyńska (red.), Metody, wyniki i konsekwencje badań kości z grobów ciatopalnych. Materiaty z sesji naukowej w dniu 25 III 1972 roku, Sesja naukowa UAM, Seria Antropologiczna nr 2, s. 7-15.

Malinowski A., Bożiłow W. 1997, Podstawy antropometrii. Metody, techniki, normy, Warszawa-Łódź.

Martin R., Saller K. 1957, Lehrbuch der Anthropologie, Stuttgart.

Piontek J. 1974, Wyniki badań antropologicznych materiałów kostnych z cmentarzysk ciałopalnych ludności kultury tużyckiej z terenu woj. zielonogórskiego, w: H. Giżyńska (red.), Metody, wyniki i konsekwencje badań kości z grobów ciatopalnych. Materialy z sesji naukowej w dniu 25 III 1972 roku, Seria Antropologiczna, nr 2, s. 137-142.

- 1999, Biologia populacji pradziejowych. Zarys metodyczny, Wydawnictwo Naukowe UAM, Poznań. Powieść minionych lat 1968, tłum. F. Siedlicki, Warszawa.

Pyżuk M. 2004, Antropologia interpretacyjna szczątków kostnych populacji kultur przeworskiej $i$ wielbarskiej z Kolozębia, pow. Płońsk, „Archeologia Polski”, t. 49, z. 1-2, s. 33-48.

Rębkowski M. 2007, Chrystianizacja Pomorza Zachodniego. Studium archeologiczne, Szczecin.

Sikorski D.A. 2011, Kościót w Polsce za Mieszka I i Bolesława Chrobrego, Poznań.

- 2012, Początki Kościoła w Polsce, Poznań.

Strzałko J., Henneberg M. 1975, Określenie płci na podstawie pomiarów szkieletu, „Przegląd Antropologiczny", t. 41, z. 1, s. 105-126.

Strzałko J., Piontek J., Malinowski A. 1972, Problem rekonstrukcji wzrostu na podstawie kości zachowanych we fragmentach lub spalonych, „Przegląd Antropologiczny”, t. 38, z. 2, s. 277-287.

- 1973, Teoretyczno-metodyczne podstawy badań kości z grobów ciatopalnych, Materiały i Prace Antropologiczne, t. 85, s. 179-201.

Ubelaker D.H. 1989, Human Skeletal Remains, Excavation, Analysis, Interpretation, Aldine Publishing Company, Chicago.

Urbańczyk P. 2015, Jak (s)chowano pierwszych chrześcijan?, w: W. Dzieduszycki, J. Wrzesiński (red.), Funeralia Lednickie, Spotkanie 17. Cmentarzyska - relacje społecznie i międzykulturowe, Poznań, s. $129-142$.

- 2020, Trudna historia zwtok, t. 1. „,Wrócisz do ziemi”, Torun.

Wrzesińska A., Wrzesiński J. 1998, Grób konia z Dziekanowic, „Studia Lednickie”, t. 5, s. 103-115.

- 2002, Wspólny grób kobiety i mężczyzny - przykład z Dziekanowic stan. 22, „Studia Lednickie”, t. 7 , s. $77-88$.

Wrzesińscy A., J. 1996, Grób „pradziejowy” z Dziekanowic, gm. Łubowo, woj. poznańskie, stan. 22, „Studia Lednickie”, t. 4, s. 325-338.

Wrzesińska A. 2016, Opracowanie antropologiczne szczątków ludzkich z grobów z monetami, cmentarzyska wczesnośredniowiecznego Dziekanowice stanowisko 22, w: J. Wrzesiński (red.), Nummus bonum fragile est. Groby z monetami wczesnośredniowiecznego cmentarzyska w Dziekanowicach, Biblioteka Studiów Lednickich 35, Fontes 7:2, s. 129-224.

Wrzesiński J. 2010, Grób ze srebrnym naszyjnikiem z Dziekanowic, w: J. Wrzesiński (red.), Srebrny naszyjnik z kaptorgami i krzyżowata zawieszka z Dziekanowic, Biblioteka Studiów Lednickich 24, seria C, t. 3, s. 13-79.

- 2016, Archeologia dziekanowickich grobów z monetami, w: J. Wrzesiński (red.), Nummus bonum fragile est. Groby z monetami wczesnośredniowiecznego cmentarzyska w Dziekanowicach, Biblioteka Studiów Lednickich 35 Fontes 7:1, s. 13-106.

Wrzesiński J. (red.) 2016, Nummus bonum fragile est. Groby z monetami wczesnośredniowiecznego cmentarzyska w Dziekanowicach, Biblioteka Studiów Lednickich 35, Fontes 7:1-2, Lednica.

Wrzesiński J. (red.) 2019, Groby z biżuteria wczesnośredniowiecznego cmentarzyska w Dziekanowicach, Biblioteka Studiów Lednickich 39, Fontes 8:1-2, Lednica.

Zoll-Adamikowa H. 1971, Próba periodyzacji wczesnośredniowiecznych praktyk pogrzebowych w Polsce, „Archeologia Polski”, t. 16, s. 541-556.

- 1971a, Wczesnośredniowieczne cmentarzyska szkieletowe Małopolski, cz. 2. Analiza, Wrocław. 
- 1979, Wczesnośredniowieczne cmentarzyska ciałopalne Słowian na terenie Polski. cz. 2, Analiza, Wnioski, Wrocław.

- 1988, Przyczyny i formy recepcji rytuatu szkieletowego u Stowian nadbałtyckich we wczesnym średniowieczu, „Przegląd Archeologiczny”, t. 35, s. 183-229.

- 1995, Modele recepcji rytuału szkieletowego $w$ Słowian Wschodnich i Zachodnich, „Światowid”, t. 40 , s. $174-184$.

Żurowska K. (red.) 1993, Ostrów Lednicki. U progu chrześcijaństwa w Polsce, t. 1, Kraków. 